\title{
Evaluation of the Reform Efficiency in Public Social Sector Management of the Republic of Kazakhstan
}

Yermek A. Buribayev

Zhambyl K. Oryntayev

Zhanna A. Khamzina

Sergazy Zh. Kussainov

Adlet T. Yermekov

Kazakh National Pedagogical University named after Abay, Republic of Kazakhstan

Email: ermek_a@rambler.ru

\section{Doi:10.5901/mjss.2015.v6n3s5p191}

\section{Abstract}

The paper aims at studying the retrospective public administration reform the social sphere, the classification of its main results, and formation of proposals for further improvement of public governance. As a result, authors implemented a comprehensive systematization of the key stages of the reform and measures taken to improve the functioning of the institute of public administration in the social sphere of the Republic of Kazakhstan in the context of administrative and social reforms. The results of the reforms are determined; the shortcomings of state control over the implementation of social programs are identified. Article suggests the prospects and directions of development of the social protection system in the Republic of Kazakhstan with an account of current socio-economic conditions and the parameters of international social standards.

Keywords: public administration, social services, social protection reform, social rights

\section{Introduction}

Arguments that determine the relevance of the present study are the changes in social sector management that have occurred in recent years. There are significant gaps in the implementation of control and supervisory functions in the ordering effects in the social sphere. Lack of legal support for the existence and implementation of social public relations, limitations of theoretical and methodological and conceptual justification of the essence, content, structure of the social management, as well as the certain fragmentation in the levels of public governance in this sector determine the course of this study.

In today's challenging financial and economic conditions, Kazakhstan is based on the priority values of the social sphere as the most important factor determining the effectiveness of state power, able to perform its social obligations under any circumstances. A personal responsibility of senior representatives of the executive authorities is set for the resolution of social problems set by the President. In Kazakhstan in the 2014 - 2015 period, all social benefits have not decreased, but rather increased the rate of inflation. In these circumstances, it is of particular urgency and relevance to scientifically analyze the problems of the reform of public administration in the social sector, the effective and full implementation of the social rights of the individual in the Republic of Kazakhstan.

The research topic was previously studied in fragments, and has still not been the subject of a comprehensive monographic study. Scientific research reflects the results of the analysis of only certain issues of legal support of the state administration in the field of social security (Khamzina, 2009), protection, participation of individual actors in the management, evaluation of the individual parameters of social reforms (Abankina et al., 2012; Zaleski, 2006; Grigorieva \& Chubarova, 2013).

Scientists have always been interested in problems of social management, not only as an independent scientific discipline (Axinn \& Stern, 2008; Khamzin \& Khamzina, 2009), but in relation to the general theoretical and legal issues determining the nature of the social state (Castles, 2010; Trattner, 2007), a system of constitutional social rights and guarantees of their implementation, execution by the state of its social functions in relation to the social interests, the 
state social policy and in the framework of public governance, and other highly relevant phenomena on the problems of social development management (Duran \& Kostin, 2011; Apostolova \& Kosevich, 2008; Abdulkerimov, 2012; Chubarova, 2004; Castells, 2008). These issues are considered in the research of many universally recognized scientists. However, analysis of the available scientific research indicates the research topic to be little studied and the need for a new comprehensive view of the matter under consideration. The specificity of the present study is its complex retrospective analysis of administrative process in the social sphere of Kazakhstan; the substantiation of effective opportunities to improve the efficiency of the social management and its legal support.

The aim of this study is based on an analysis of the legal sources for social reform, the achievements of modern domestic and foreign scientific ideas to analyze the complex issues related to the dynamics of the relationship management of social sphere, paying special attention to the efficiency of the state social function. Research objectives require undergoing a retrospective study and analysis of the current state of reform in public administration of the social sector, ordering their main outcomes; analysis and offer solutions to problems of legal support as to increase the efficiency of public administration reform in the social sphere.

\section{Public Administration Reform in the Social Sector}

The process of reforming the social sphere has started since the Republic of Kazakhstan gained its independence, not being complete up-to-date. The research problem should be viewed from two perspectives: in terms of changes in social services governance, coupled with the social reforms carried out, and from the perspective of the ongoing administrative reform. The chosen approach for the study is build on analyzing the problem in conjunction with all relevant processes in the society and the state, involves a complete study of applying for reliable and valid conclusions.

The paper involves inductive, deductive, target-oriented, structural and functional methods of data analysis. The problem of public administration reform in the social sector is interdisciplinary in nature, covering the subjects of sociology, political, economic, legal sciences, which explains the appeal to the theoretical basis of the relevant research theory of administrative and legal science.

During the Soviet period of the development of Kazakhstan, the social protection was based on the principle of universal provision of solidarity system by reallocating the state budget within a single planning process. The state was combining the roles of ensuring participation in the social system, distributing the material resources and exercising control over the system functioning. However, with the acquisition of the independence by the Republic and the beginning of market reforms, the government was faced with the inefficiency of the social system directly as well as the principles of public governance. The problem were a lack of sufficient funds allocated for social purposes, ineffective management of available resources. The situation was aggravated by a sharp decline in the number of economically active population, in particular the disabled persons, rising unemployment, demographic situation, according to which the observed steady decline in the number of persons of working age with respect of pensioners. The economy in transition did not allow having sufficient resources to fulfill all previous obligations of the state.

In general, in designated conditions the government was forced to begin the reform of the social sector, corresponding to the principles of building a social state with a market economy, in which the social sphere is recognized as a priority. The reform was carried out in stages, but covered almost all social risks and forms of social protection. In fact, social reform was aimed at excluding the structure inherent in solidarity systems, which do the accumulation of funds allocated for social purposes, and distribution of material resources that make up the sources of financing of social activities, the provision of social benefits. In the context of market reforms, the construction of the economy on new principles, the solely redistributive duties of these structures proved ineffective. There has been a misuse of funds. Significant amounts of earmarked funds were not included in economic activity, there was no personal interest of recipients of payments to implement social benefits on time and in full, the duration of participation in the formation of funds by the recipients of social payments and the amount of contributions made were not taken into account.

The foregoing factors combined with the difficult economic situation in the country, characterized by a lack of adequate funding for social measures, have led to a situation in which the government was forced to start a social reform that was unpopular at that time among the population. The public administration reform in the social sector is presented in table 1. 
Table 1. Public administration reform in the social sector

\begin{tabular}{cl}
\hline Period & Main directions and results \\
\hline \multirow{2}{*}{$1997-1999$} & $\begin{array}{l}\text { Formation of a national system of social protection and security; exclusion of specific entities, inherent in the Soviet } \\
\text { system, for distributing means for the financing of social activities and benefits; reform in the forms of social security } \\
\text { and social risks }\end{array}$ \\
\hline $2001-2005$ & $\begin{array}{l}\text { Formation of the national funded pension system, assistance to poor, determine the status of entities engaged in } \\
\text { the management of the pension system }\end{array}$ \\
\hline \multirow{2}{2007-2010}{$\begin{array}{l}\text { Introduction of the principle of responsibility of local governments for the organizational and financial support of } \\
\text { certain forms of state obligations in social protection; introduction of a single system of electronic services to } \\
\text { citizens against social risks; improving governance mechanism for funded pension system and the social security } \\
\text { system }\end{array}$} \\
\hline $2011-2014$ & $\begin{array}{l}\text { Elimination of pension funds, creation of a single public fund, development and phased implementation of state } \\
\text { standards of social services }\end{array}$ \\
\hline
\end{tabular}

As a result, the first phase of social reforms of 1997-1999 happened:

- The gradual increase in the retirement age;

- Exclusion, of favorable grounds for pension payments, with a few exceptions, conjugate with the reduced retirement age;

- Cancelation of the social disability pensions, loss of the breadwinner, introduction of state social benefits on these social risks;

- Introduction of a funded pension system, being of mandatory participation;

- the National Center for pension payments was established, whose functions are to directly make payments of pensions and benefits from the budgetary funds; the implementation of a personalized account of mandatory pension contributions; transfer of compulsory pension contributions from contributors to pension funds;

- Were eliminated special structures involved in the governance of pensions and social insurance relations. Funding for this area has begun to be carried out directly from the budget without the formation of special distribution funds;

- Eliminated the previous social security system from the national social protection system. The burden of social payments on social insurance risk has been transferred to other sources: a means of employers, the republican budget, personal retirement savings. In the period from $1^{\text {st }}$ of January 1999 to $1^{\text {st }}$ of January 2005 there was no overall system of social insurance on any social risks in Kazakhstan.

The second stage of social reform (1997 - 1999) characterized by a refusal to provide social benefits in natural value (i.e. in-kind benefits), introducing, in return, of a special government allowances. Replacing the preferential grounds for a pension with special state benefits, and a shift of burden of benefit payments for maternity leave from the State Social Insurance Fund of Kazakhstan to employers, the exception of compulsory social insurance of the social system, the abolition of a number of social benefits for unemployment, wellness services for workers and their families at the expense of special funds, and others.

The Concept of Social Protection (2001), approved by Government Resolution dated June 27, 2001 N 886, which was the program of further reforms of the social sphere, pointed out that at the initial stage of the transition period, the state was forced to deal with current issues of social protection against the background of inflation, budget deficit, recession production, increasing the share of the informal sector of the economy. As a result, reforms in the social sector were fragmentary, as a response to the current problems, except for the introduction of a funded pension system and the replacement of in-kind benefits with cash payments.

Favorable economic changes since the late 90 s of the last century and the beginning of the 2000s allowed the move to create a comprehensive system of social protection against social risks. In this regard, there was a need to develop the aforementioned Concept of social protection of the population based on the priorities and opportunities of Kazakhstan in the present and the future.

The concept was designed for the implementation of the following measures: a) the introduction of compulsory insurance of employer's liability for harm to the life and health of the employee in the performance of duties; b) the introduction of social security against disability, loss of the breadwinner or work; c) transition to the appointment of social benefits on the basis of a single registration code of a natural person; d) gradual approximation of the minimum wage to a subsistence level; e) development of new forms of targeted assistance to needy citizens, including in the required forms of assistance from the budget of lump sum the benefits at birth, payments to families raising minor children. 
Analysis of the current state of the social sphere has shown that most of the measures provided by the Concept are implemented. However, measures such as the transition to the appointment of social benefits on the basis of a single registration code of a natural person, the development of new forms of targeted assistance to needy citizens remain unfulfilled.

It should be noted that the reforms of 2001 - 2005 did not include measures to improve organizational forms of social benefits, as well as measures to improve the efficiency of public administration in this area and the use of budget funds, as well as the development of organizational forms of social services, of social activities, as well as improved control of the legality in the social sphere, that, in our opinion, was a significant drawback of reforms, since the complexity and systemic change has been neglected.

Later reforms were implemented in a sectoral manner. There were adopted and implemented the "Development Program for funded pension system of Kazakhstan for 2005 - 2007", the "Program to combat poverty and unemployment for the period 2000 - 2002", the "Program for Reducing Poverty in the Republic of Kazakhstan for 2003 - 2005". The latter document on part of improving the institutions of society to reduce poverty provides measures to improve the activity of state agencies to reduce poverty; participation activities of non-governmental organizations and associations of trade unions to reduce poverty; measures for the participation of the private sector to reduce poverty and promote the involvement of vulnerable groups in decision-making on poverty. In this regard it was supposed to strengthen the control over the spending of budget funds allocated for the provision of social services, targeted assistance; ensure the activities of the permanent consultative and advisory committees on poverty reduction with the help of community organizations; prepare the proposals for the establishment of an institute of social workers in Kazakhstan using the experience of Western countries; enhance the role of social partnership in addressing issues of poverty reduction in determining the priorities of the territories, as well as the organization of monitoring and evaluation of aid effectiveness, taking into account the vulnerable groups and more.

As of today, we can say that not all the provisions of the program concerning the improvement of mechanisms of activity of state institutions and society in reducing poverty and unemployment found its full implementation. Firstly, due to declarative nature of individual provisions and, secondly, due to the adoption such forms of control over their execution over many of the provisions as the provision of information to the authority. Thus, in the above mentioned program to combat poverty provided a little more than ninety specific activities, which in their totality constitute an action plan for implementation of this program. More than sixty events should be completed by the provision information to the Government of the Republic of Kazakhstan by the responsible authorities. We suggest this form of the final work on the implementation of the state program is invalid because, in essence, the study of information, analysis, processing activities are forms that must precede the establishment of the program and cannot act as a result of its implementation. The use of this form makes the program useless for solving its goals and objectives. Reduction of poverty and unemployment cannot be by achieved providing information to the authorized body, since the collection and processing of information are everyday forms of public authorities.

In accordance with the legislation, the program must possess a basic property of clarity of the definition of the specific ways and mechanisms for their implementation. The election of such an element as the preparation of information to the authorized body in the mechanism of implementation of the program denies the program properties to achieve the goals and objectives that actually leads to a declarative nature of programs. In view of the above, we consider it necessary, first, to implement legally binding obligation to the mechanism of implementation of programs and, secondly, to eliminate the use of forms of programs - preparation of information. Moreover, for the reasons stated above it is unacceptable to state the preparation of proposals to the authority as the final type of work in the mechanism of program implementation. On the basis of the collected and analyzed information on a certain issue, must be the proposals to the authorized agency. In turn, the development of complex sectoral programs with concrete steps to achieve the goals and objectives should be based on this data.

Further reform of the social sphere was carried out on the basis of the sectoral "Program for the further deepening of social reforms in the Republic of Kazakhstan for 2005 - 2007" (2004). One of the main objectives of its implementation was to improve the management of the social security system, which included mechanisms such as: 1) the regional dimension of social reform deepening, 2) improving information security and social statistics, 3) staffing.

The first area indicated that the deepening of social reforms requires further optimization and redistribution of system management functions of social security between the central and local government agencies. The following challenges in the implementation of the program were nominated to the central executive body: the formation of a national social security policy, the development of approaches to phase alignment of the conditions for accessibility of regional social services, methodological assistance in the design and implementation of social development programs of the regions. The second area indicated on work to create a unified system of electronic services to citizens, and the third 
aspect involves the creation of conditions for advanced training of personnel of the social security system.

It should be noted that almost all measures provided within the program under study is aimed at further improving the management of the social sphere and providing a concrete form of records for the completed activities.

Further stages of social reforms related to the implementation of "The medium-term plan of socio-economic development of the Republic of Kazakhstan for 2008 - 2010", where an increase the level of pension and social security of the population, as well as further improvement of the legislation is indicated as the purpose of measures to improve the social security system.

The follows objectives were set in order to achieve this goal: gradual increase in the amount of the basic state pension payments (at $40 \%$ of the subsistence minimum); introduction of additional benefits for persons with a work out experience in hazardous and harsh working conditions by 1 January 1998; expanding of coverage of funded pension system services; compulsory social insurance for working women in case of pregnancy, childbirth and child care until the child reaches the age of one year; ensure transparency of accumulative pension funds. However, from the above mentioned objectives of the social sphere, have been resolved only those that are clearly defined in terms of the parameters that need to be achieved and addressed. Tasks with a formally undefined, but in essence, a declarative character, did not find their solutions. Including: expanding population coverage with funded pension system service; ensure transparency of accumulative pension funds.

In general, the public administration reform of the social sector, as already noted, cannot be considered in isolation from the ongoing reforms of public administration across the state. In this aspect, the system of social sector governance has gone through all the stages of the administrative reform that took place throughout the formation and development of our state. In our view, there are several important steps in the reform of the social sector.

1. Establishment of national public authorities engaged in social sector governance after gaining sovereignty and independence of the Republic of Kazakhstan (RK).

2. Structural optimization of public authorities, a redistribution of functions and powers.

3. Partial amplification of decentralization of government guarantees over realization of the social rights of the individual, as expressed in the introduction in 2001 of targeted social assistance in to the national social security system. It has become a form of financial support for people (families) with the lowest income, funded by the local budgets, appointed by the local executive bodies, but guaranteed by a centralized regulatory legal act - the RK Law of July 17, 2001 № 246-II "On state targeted social assistance". Social assistance is a means of combating poverty by raising incomes to a subsistence minimum (i.e. living wage). A subsistence minimum is the required minimum amount of cash income per person equal in magnitude to the minimum consumer basket, which in turn includes the cost of the food basket and the cost of non-food goods and services. The poverty line is determined on a quarterly basis at a rate of 40 per cent of the cost of the minimum necessary non-food products and services of the subsistence minimum. The right to targeted social assistance is granted to citizens with incomes not exceeding the poverty line.

4. Improving public administration of the funded pension system and the social security system, which included the emergence of new structures in the control system, the reform of the principles and techniques of social benefits.

The process of public administration reform of the social sphere corresponds with the goals and objectives of the administrative reform, and the expected results are derived from the expected outcome of the administrative reform. In general, it can be argued that the reform of social management is an integral part of the administrative reform. While social transformations consist of two main areas: changes in the forms and methods of social benefits, i.e. the structure of material social relations and transformation of public administration system of the social objects, the subjects of social relations. In this case, the above two areas cannot be considered in isolation from each other, since these processes are interrelated and interdependent.

Particular attention should be given to the development and implementation of standards of public social services in government agencies and organizations that provide social services directly to the public. We believe that this aspect requires a comprehensive approach to each social group, for each type of social risk, fact. Thus, we believe it is necessary to carry out the development of standards of social services in confirming the following life events, defined as social facts: disability (both general and special, either fully or partially); retirement age; loss of breadwinner; work in special conditions; birth of a child; adoption of the child; monthly income of a person or the whole family below the poverty line; participation in hostilities; living in areas exposed to environmentally adverse factors, and the impact on the face the consequences of nuclear testing; a socially significant disease; a family of four or more children; the impact of measures on the face of political repression; unemployment and some other.

Next, is it needed to carry out more detailed differentiation of public services, such as distinguish between the 
social standards of disabled of the first, second, and third groups, children with disabilities, are the essential differences in the provision of certain services depending on the criteria of disability (disability due to general or occupational disease, due to wound, injury, disease, obtained during military service). Only with the more socially significant differentiation of facts, it is possible to provide objective and social justice enshrined in norms and standards of the volumes of public social services. In this aspect, we believe it possible to highlight and develop a separate standard of public services for social services in special social institutions.

\section{Public Governance and Control Over the Social Sector}

The analysis of the social control structure over the social sector leads to the conclusion that the government system lacks a responsible body for supervising compliance with social legislation and social rights, and also responsible for the creation and adherence to the rule of law in the social sphere. In this regard, of particular relevance are such areas of administrative reform, as the development of a system of annual evaluation and audit the effectiveness of central and local government bodies in this field; development and implementation of rating system of public authorities, taking into account the degree of achievement of strategic objectives, the quality of public services, the effectiveness of the implementation of policy documents and other indicators; regular public opinion polls as to assess the quality of public social services; creation of a system for evaluating the performance of civil servants in the social sector.

The above mentioned and other areas of administrative reform, such as improvement of the governance structures; ensuring the optimal number of employees in state bodies and organizations; development of proposals for improving the remuneration system of employees in state bodies and organizations also fully apply to the social sphere of public administration. Salaries of social workers is the lowest, with significant functional load per employee. According to the Agency for Statistics of Kazakhstan, in 2008 the amount of 505 USD was the average republican salary, whereas the salary in the field of health and social service provision was 299 USD. A similar trend of significant backlog is constantly observed in the following official statistical reports. The average monthly nominal wage per employee amounted to 679 USD in 2012, 717 USD in 2013, and 668 USD in 2014. At the same time, the wages of social workers was 541 USD in 2012, 540 USD in 2013, and 350 USD in 2014. That is an average of 30 percent lag in payment of social workers from the nationwide salaries (over the past three years).

Allocated problem has become one of the objectives of the program implemented in Kazakhstan - "Employment Roadmap 2020". One of its objectives - a new model of the system of remuneration of civil servants, which is being implemented from the $1^{\text {st }}$ of July 2015 . The roadmap provides increase in wages of employees in state institutions and state-owned enterprises, up to $28 \%$ in health sector, education - up to $29 \%$, and up to $40 \%$ in other areas, aimed at overcoming the backlog in salaries from wages in the private sector and the economy in general.

The current stage of public administration reform in social sector is associated with the adoption and implementation of the Concept of further modernization of the pension system of Kazakhstan until 2030 (The concept..., 2014). The purpose of the Concept of modernization of the pension system is to increase the pensions of citizens. For these purposes, the distribution of responsibility for the pensions of citizens among the workers, employers and the state is provided. Thus, workers will produce the transfer of $10 \%$ of compulsory pension contributions from wages in the Single accumulative pension fund. Employers will transfer $5 \%$ of payroll to employees. This system will be as notional defined contribution, including both cumulative and solidarity principle. Cumulative principle is that the account will be opened in the accumulation fund, savings are invested, and solidarity - is that the pension is paid for lifetime. The state will pay the basic pension depending on seniority or experience of participation in the pension system. Thus, it is assumed to leave the principle of "egalitarianism" in the appointment of the basic pension. In accordance with current amendments, $50 \%$ of the subsistence minimum will receive persons with seniority of 10 years, 20 years $-70 \%, 35-100 \%$ of the subsistence minimum. It is expected that by the $1^{\text {st }}$ of July 2017 about 2 million pensioners will be held a recalculated basic pension and the additional requirements for the annual payments will be one and a half billion US dollars.

The final area of reforming the public policy in the social sector are the changes of ideology of social assistance. It involves the introduction of conditional social assistance for low-income families with able-bodied family members. Conditionality is as follows - the able-bodied member of the family takes a responsibility to pass adaptation services or participate in active measures to promote employment, while the local executive bodies undertake responsibilities to pay a targeted social assistance amounting to $60 \%$ of the subsistence minimum for each family member.

\section{Concluding Remarks}

Social reform is a multifaceted, complex phenomenon, being conditionally divided into separate stages and isolated 
areas. Current analysis shows the social sphere is being reformed until now, while the main directions in this area are:

- use of existing and creation of new secure instruments for financing the pension savings;

- provision of state guarantees of the safety of pension savings;

- ensuring the right to a pension on preferential basis to persons engaged in labor activity in special conditions;

- raising the minimum subsistence level by expanding the list of norms of its components;

- an increase in the level of social security to a living wage for persons with disabilities, survivors, the elderly, women caring for children up to three years of age;

- coverage of all social risks by the social security system;

- development and implementation of social standards of appropriate social services;

- creation of a system monitoring the state of a mode of legality in the social sphere and the quality of social services;

- implementation of measures stimulating the attraction of highly qualified specialists in to social work.

Outlined vectors of the state activities in the social sphere imply a continuation of measures for social reform and related processes in the legal sphere of the state, as a necessary tool to perform the constitutional guarantees of social rights of citizens of Kazakhstan. Thus, based on a comprehensive analysis of the characteristics of the social reforms in Kazakhstan, authors identified the main important steps in reforming the governance of social sector: 1) the establishment of national governance bodies in the social sector after gaining sovereignty and independence of the Republic of Kazakhstan; 2) structural optimization of public authorities, a redistribution of functions and powers in order to create a single body eligible to social management, as well as increased financial control over the activities of the funded (i.e. accumulative) pension system; 3) partially increased decentralization of government guarantees over the social rights of the individual; 4) improvement of public administration of the funded pension system and the social security system, which included the development of new control structures and reform of the principles and techniques of social benefits; 5) the current stage, which includes a comprehensive reform of the social management: the development and implementation of social standards, improvement of social legislation; implementation of the principles of universality, combined with an individual approach in the provision of social benefits and other areas, corresponding with the main directions of the administrative reform carried out in Kazakhstan.

The main areas of public administration reform in the social sector until 2020 in Kazakhstan, with an account of national circumstances and international experience should be: a) improvement of the system of support for mothers and children in order to create favorable conditions to encourage fertility, support large families and young families with children; b) resolving the simultaneous employment of young people, people of pre-retirement and old age; c) improvement of external migration in order to attract highly qualified specialists and create an open market to attract foreign labor; d) take into account the recommendations of international institutions of social activity on the approximation of national labor standards to the standards of developed countries; e) improvement of the mechanism for the appointment of state basic pension at a basic level in order to reduce poverty among pensioners and encourage citizen participation in the pension system; f) introduction of an additional compulsory component of pensions - notional defined contribution (NDC), formed from $5 \%$ of employer contributions for the benefit of its employees; $\mathrm{g}$ ) introduction of new forms of conditional cash assistance, in the form of the contract system, providing active support with mandatory participation in vocational training and retraining, job search and placement services; $h$ ) continuation of reforms in the system of special social services.

\section{References}

Abankina, I.V., Abankina, T., Nikolayenko, E., Seroshtan, E., \& Filatova, L. (2012). The Effects of Reform on the Performance of Higher Education Institutions. Journal of Applied Research in Higher Education, 4 (1), $23-41$.

Abdulkerimov, K.K. (2012). Development and Implementation of social policy in modern Russia. Modern problems of science and education, 6. [Online] Available: www.science-education.ru/106-7481 (March 20, 2015).

Apostolova, T.M., \& Kosevich, N.R. (2008). Social policy and legal framework for its implementation: a tutorial. Moscow: VLADOS.

Axinn, J., \& Stern, M.J. (2008). Social Welfare: A History of the American Response to Need (7th ed.). Boston, MA: Pearson/Allyn and Bacon.

Castells, M. (2008). The New Public Sphere: Global Civil Society, Communication Networks, and Global Governance. The Annals of the American Academy of Political and Social Science, 616 (1), 78-93.

Castles F.G. (2010). The Oxford Handbook of the Welfare State. Oxford University Press.

Chubarova, T. (2004). Social Policy and Health Care Reform in Russia. In: G. Hinterregger, \& H.-G. Heinrich (eds.). Russia-Continuity and Change. Springer, Wien - New York.

Concept of becoming one of the 30 most developed countries of the world (2014). Approved by Decree of the President of the Republic 
of Kazakhstan, 732 (January 17, 2014).

Development Programme for funded pension system of Kazakhstan for 2005-2007 (2004). Approved by the Government Decree 1359 (December 24, 2004).

Duran, T.V., \& Kostin, V.A. (2011). On the concept of "efficiency" in the management. Scientific Bulletin of the Ural Academy of Public Administration: political science, economics, sociology, and law, 2, 138-143.

Employment road map 2020 (2013). Approved by the Government of the Republic of Kazakhstan, 636. (June 19, 2013).

Grigorieva, N., \& Chubarova, T. (2013). Patterns of health care reforms in economies under transition: a case of Russia. In J. Bjorkman \& J. Nemec (eds.) Health Reforms in Central and Eastern Europe. Options, Obstacles, Limited Outcome. Hague: Eleven International Publishing.

Khamzin, A. S, \& Khamzina, Zh. A. (2009). Problems of activity of the state to ensure social rights in Kazakhstan: the constitutional and legal research. Astana.

Khamzina, Zh. A. (2009). State management in the social sphere of the Republic of Kazakhstan (theoretical and legal aspect). Astana.

Program for reducing poverty in the Republic of Kazakhstan for 2003-2005 (2003). Approved by Government Resolution, 296. (March $26,2003)$.

Program to combat poverty and unemployment for the period 2000-2002 (2000). Approved by Government Resolution, 833. (June 3 , 2000).

The concept of social development of the Republic of Kazakhstan to 2030 and social modernization plan for the period until 2016 (2014). Approved by the Government of the Republic of Kazakhstan (April 24, 2014).

The concept of Social Protection (2001). Approved by Government Resolution, 886. (June 27, 2001).

The medium-term plan for socio-economic development of the Republic of Kazakhstan for 2008-2010 (2007). Approved by Government Resolution, 753. (August 29, 2007).

The Program for the further deepening of social reforms in the Republic of Kazakhstan for 2005-2007 (2004). Approved by Government Resolution, 1241. (November 30, 2004).

Trattner, W.I. (2007). From Poor Law to Welfare State, 6th Edition: A History of Social Welfare in America. Free Press.

Zaleski, P., (2006). Global Non-governmental Administrative System: Geosociology of the Third Sector. In D. Gawin \& P. Glinski (ed.) Civil Society in the Making. Warszawa: IFiS Publishers. 